\title{
Polynucleobacter cosmopolitanus sp. nov., free-living planktonic bacteria inhabiting freshwater lakes and rivers
}

Correspondence

Martin W. Hahn

martin.hahn@oeaw.ac.at

\author{
Martin W. Hahn, ${ }^{1}$ Elke Lang, ${ }^{2}$ Ulrike Brandt, ${ }^{1}$ Heinrich Lünsdorf, ${ }^{3}$ \\ Qinglong L. Wu ${ }^{1,4}$ and Erko Stackebrandt ${ }^{2}$
}

\author{
${ }^{1}$ Institute for Limnology, Austrian Academy of Sciences, Mondseestrasse 9, 5310 Mondsee, Austria \\ ${ }^{2} \mathrm{DSMZ}$ - Deutsche Sammlung von Mikroorganismen und Zellkulturen GmbH, Inhoffenstraße 7B, \\ D-38124 Braunschweig, Germany \\ ${ }^{3}$ Helmholtz Center for Infection Research (formerly GBF), Electron Microscopy Laboratory, \\ Inhoffenstraße 7B, D-38124 Braunschweig, Germany \\ ${ }^{4}$ State Key Laboratory of Lake Science and Environment, Nanjing Institute of Geography and \\ Limnology, Chinese Academy of Sciences, East Beijing Road 73, Nanjing 210008, PR China
}

\begin{abstract}
Five heterotrophic, aerobic, catalase- and oxidase-positive, non-motile strains were characterized from freshwater habitats located in Austria, France, Uganda, P. R. China and New Zealand. The strains shared $16 \mathrm{~S}$ rRNA gene similarities of $\geqslant 99.3 \%$. The novel strains grew on NSY medium over a temperature range of $10-35{ }^{\circ} \mathrm{C}$ (two strains also grew at $5{ }^{\circ} \mathrm{C}$ and one strain grew at $38{ }^{\circ} \mathrm{C}$ ) and a $\mathrm{NaCl}$ tolerance range of $0.0-0.3 \%$ (four strains grew up to $0.5 \% \mathrm{NaCl}$ ). The predominant fatty acids were $\mathrm{C}_{16: 0}, \mathrm{C}_{18: 1} \omega 7 c, \mathrm{C}_{12: 0} 3-\mathrm{OH}$, and summed feature 3 (including $\left.\mathrm{C}_{16: 1} \omega 7 \mathrm{c}\right)$. The DNA G $+\mathrm{C}$ content of strain $\mathrm{MWH}-$ Molso $2^{\top}$ was $44.9 \mathrm{~mol} \%$. Phylogenetic analysis of $16 \mathrm{~S}$ rRNA gene sequences demonstrated that the five new strains formed a monophyletic cluster closely related to Polynucleobacter necessarius (96-97\% sequence similarity). This cluster also harboured other isolates as well as environmental sequences which have been obtained from several habitats. Investigations with taxon-specific FISH probes demonstrated that the novel bacteria dwell as free-living, planktonic cells in freshwater systems. Based on the revealed phylogeny and pronounced chemotaxonomic differences to $P$. necessarius (presence of $>7 \% \mathrm{C}_{12: 0} 3-\mathrm{OH}$ and absence of $\mathrm{C}_{12: 0}$ and $\left.\mathrm{C}_{12: 0} 2-\mathrm{OH}\right)$, the new strains are suggested to represent a novel species, for which the name Polynucleobacter cosmopolitanus sp. nov. is

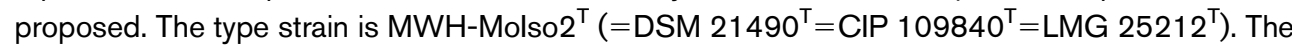
novel species belongs to the minority of described species of free-living bacteria for which both in situ data from their natural environments and culture-based knowledge are available.
\end{abstract}

The genus Polynucleobacter was described by K. Heckmann and H.-J. Schmidt for bacterial endosymbionts of freshwater ciliates within the genus Euplotes. The species Polynucleobacter necessarius was erected for obligate endosymbionts living in the cytoplasm of Euplotes aediculatus (Heckmann \& Schmidt, 1987). Phylogenetic analysis of the 16S rRNA gene sequence of an endosym-

Abbreviations: FAMEs, fatty acid methyl esters; FISH, fluorescent in situ hybridization; Mbp, mega base pairs; ML, maximum-likelihood; $\mathrm{NJ}$, neighbour-joining; OD, optical density; PFGE, pulsed field gel electrophoresis.

The GenBank/EMBL/DDBJ accession numbers for the 16S rRNA gene sequences of strains $\mathrm{MWH}-\mathrm{Molso} 2^{\top}$, MWH-CaK1, MWH-VicM1, MWHTaW3 and MWH-NZ8W13 are AJ550672, AJ550667, AJ550651, AJ550661 and AM110084, respectively. biotic $P$. necessarius strain in a culture of $E$. aediculatus revealed the affiliation of the strain to the class Betaproteobacteria (Springer et al., 1996). Recently, it was demonstrated that the obligate endosymbionts representing the species $P$. necessarius are closely related to obligately free-living strains (Hahn, 2003; Vannini et al., 2007). Therefore, the description of the genus Polynucleobacter and its sole species, $P$. necessarius, was emended by the addition of descriptions of free-living strains (Hahn et al., 2009). Due to the very pronounced differences in lifestyle of the obligately endosymbiotic and obligately free-living strains, the placement of these organisms in two subspecies $P$. necessarius subsp. necessarius (for endosymbionts of $E$. aediculatus and Euplotes harpa) and P. necessarius subsp. asymbioticus (for obligately free-living strains) was proposed (Hahn et al., 2009). The obligately free-living 
P. necessarius strains represent aerobic chemo-organotrophic, non-motile bacteria. Cultivation-independent investigations by fluorescent in situ hybridization (FISH) with $P$. necessarius-specific probes have demonstrated that the free-living strains possess a planktonic lifestyle and inhabit a large variety of freshwater habitats (Hahn et al., 2005; Wu \& Hahn, 2006; Salcher et al., 2008; Alonso et al., 2009).

In previous studies, strains have been isolated or sequences obtained by cultivation independent approaches. Such strains were phylogenetically closely related to $P$. necessarius but did not cluster in trees together with strains of $P$. necessarius (Crump et al., 1999; Zwart et al., 2002; Hahn, 2003; Watanabe et al., 2009). Therefore, these isolates were grouped in separate species-like operational taxonomic units (designated subclusters A, B, C and D), which were defined by phylogenetic reconstructions (Hahn, 2003). In the present study, five strains affiliated to the so-called subcluster D (PnecD) of the Polynucleobacter cluster (Hahn, 2003; Wu \& Hahn, 2006) were characterized. These strains share many phenotypic, chemotaxonomic and ecological traits with strains of $P$. necessarius subsp. asymbioticus, but can be distinguished from them by phylogenetic and chemotaxonomic traits. Based on these differences, a second species within the genus Polynucleobacter is proposed.

\section{Isolation and characterization}

All five strains investigated were isolated by using the filtration-acclimatization method (Hahn, 2003; Hahn et al., 2004) with samples obtained from freshwater habitats located in Austria, France, New Zealand, China, and Uganda (Table 1). These habitats were located in temperate, subtropical and tropical climatic zones. Four strains were isolated from the surface waters of lakes, but one strain was isolated from a navigable channel fed with water from the River Loire, France. A recent investigation has demonstrated that strains closely related to the five strains characterized in this study could be directly isolated from agar plates with modified R2A medium (Watanabe et al., 2009).

All strains investigated were routinely grown on NSY medium (Hahn et al., 2004) at a strength of $3 \mathrm{~g} \mathrm{l}^{-1}$. All strains also grew on R2A medium and Bacto peptone, at least when concentrations were lowered to $3 \mathrm{~g} \mathrm{l}^{-1}$ (Hahn, 2003). Growth at different temperatures and growth under anoxic conditions in an anaerobic chamber were examined

Table 1. Characteristic traits of the five novel strains

Strains: 1, MWH-MoIso2 ${ }^{\mathrm{T}}$ (=DSM 21490 ${ }^{\mathrm{T}}$ ); 2, MWH-CaK1 (=DSM 21494); 3, MWH-VicM1 (=DSM 21486); 4, MWH-TaW3 (=DSM 21487); 5 , MWH-NZ8W13 (=DSM 21488); 6, P. necessarius subsp. asymbioticus (QLW-PIDMWHA-1 ${ }^{\mathrm{T}}$, MWH-JaK3, MWH-MoK4, MWH-HuW1). All strains show the following characteristics: DAPI stained cells only rarely show nucleoid-like structures, non-motile, catalase- (strain MWH-TaW3 only weakly positive) and oxidase-positive. -, Negative; +, positive; w, weakly positive; ND, not determined.

\begin{tabular}{|c|c|c|c|c|c|c|}
\hline Characteristic & 1 & 2 & 3 & 4 & 5 & 6 \\
\hline \multicolumn{7}{|l|}{ Origin } \\
\hline Country & Austria & France & Uganda & PR China & New Zealand & - \\
\hline Climatic zone & Temperate & Temperate & Tropical & Subtropical & Temperate & - \\
\hline \multicolumn{7}{|l|}{ Morphological characteristics } \\
\hline Cell length $(\mu \mathrm{m})$ & $0.5-1.2$ & $0.5-1.4$ & $0.4-1.1$ & $0.5-1.2$ & $0.5-1.2$ & $0.5-2.9$ \\
\hline Cell width $(\mu \mathrm{m})$ & $0.3-0.5$ & $0.3-0.5$ & $0.3-0.5$ & $0.3-0.5$ & $0.3-0.5$ & $0.3-0.5$ \\
\hline \multicolumn{7}{|l|}{ Physiological characteristics } \\
\hline Min. temp. for growth $\left({ }^{\circ} \mathrm{C}\right)^{*}$ & $5(w)$ & 5 & 10 & $5(w)$ & 5 & 5 \\
\hline Max. temp. for growth $\left({ }^{\circ} \mathrm{C}\right)^{*}$ & $35(w)$ & $35(w)$ & 38 & 38 & 35 & $30-35$ \\
\hline \multicolumn{7}{|l|}{ Other traits } \\
\hline Genome size (Mbp) & $\mathrm{ND} \dagger$ & $\mathrm{ND}^{\dagger}$ & $\mathrm{ND}^{\dagger}$ & $\mathrm{ND} \dagger$ & $\mathrm{ND} \dagger$ & $2.1-2.5$ \\
\hline DNA G $+\mathrm{C}$ content $(\mathrm{mol} \%)$ & 44.9 & ND & ND & ND & $\mathrm{ND}$ & $44-46$ \\
\hline
\end{tabular}

${ }^{\star}$ Temperature range investigated, $5-38{ }^{\circ} \mathrm{C}$.

$\dagger$ Genome sizes of 1.9-2.1 Mbp have been determined for other strains presumed to belong to P. cosmopolitanus sp. nov. (Vannini et al., 2007). 
on NSY agar. $\mathrm{NaCl}$ tolerance was determined using NSY agar supplemented with different $\mathrm{NaCl}$ concentrations $(0$, $0.1,0.2,0.3,0.4,0.5,0.6,0.7,1.0,1.25,1.5,1.75$ and $2.0 \%$, $\mathrm{w} / \mathrm{v})$. The temperature range for growth was tested on NSY agar plates exposed to different temperatures $(5,10,15,20$, $30,33,34,35,36$ and $38{ }^{\circ} \mathrm{C}$ ). Two of the four strains tested grew weakly on an inorganic mineral medium (Hahn et al., 2004) supplemented with acetate as the sole carbon and energy source and vitamin B12 (Table 1). However, of three strains tested, all utilized acetate (Table 2) when this substrate was offered in combination with the complex NSY medium (see below). The novel strains shared weak growth performance on medium with a sole carbon source with previously investigated strains of $P$. necessarius subsp.

Table 2. Utilization patterns of three novel strains compared with data reported for strains of free-living $P$. necessarius (Hahn et al., 2009)

Strains: 1, MWH-MoIso2 ${ }^{\mathrm{T}}$; 2, MWH-CaK1; 3, MWH-VicM1; 4, P. necessarius subsp. asymbioticus (four strains). All strains tested were similar to P. necessarius subsp. asymbioticus in that they did not utilize glycolate, oxalate or L-serine and that they were able to utilize acetate, pyruvate and succinate. The results for $P$. necessarius subsp. asymbioticus are from four strains. Only one symbol is given if all four strains showed a uniform response, otherwise the different responses are presented separated by a slash. -, Negative; + , positive; W, weakly positive.

\begin{tabular}{|c|c|c|c|c|}
\hline Assimilation of & 1 & 2 & 3 & 4 \\
\hline L-Alanine & + & W & + & w/- \\
\hline L-Asparagine & - & - & - & $\mathrm{w} /-$ \\
\hline L-Aspartate & - & - & - & $+1-$ \\
\hline Betaine & - & - & - & $\mathrm{w} /-$ \\
\hline Citric acid & - & + & - & - \\
\hline L-Cysteine & + & + & + & $+/ \mathrm{w}$ \\
\hline Formic acid & - & - & - & $\mathrm{w} /-$ \\
\hline D-Fructose & - & - & - & $\mathrm{w} /-$ \\
\hline D-Fucose & - & - & - & $\mathrm{w} /-$ \\
\hline Fumaric acid & + & + & + & $+/ \mathrm{w}$ \\
\hline D-Galactose & $\mathrm{W}$ & W & $\mathrm{W}$ & $\mathrm{w} /-$ \\
\hline D-Galacturonic acid & + & + & $\mathrm{W}$ & $\mathrm{w}$ \\
\hline D-Glucose & - & W & - & $\mathrm{w} /-$ \\
\hline L-Glutamate & - & $\mathrm{w}$ & - & $+1-$ \\
\hline Glyoxylic acid & - & $\mathrm{w}$ & - & $\mathrm{w} /-$ \\
\hline Levulinic acid & $\mathrm{w}$ & - & - & $\mathrm{w} /-$ \\
\hline D-Lyxose & - & - & - & $\mathrm{w} /-$ \\
\hline Malic acid & + & + & + & $+/ \mathrm{w}$ \\
\hline Malonic acid & - & + & + & $+1-$ \\
\hline D-Mannose & - & $\mathrm{W}$ & - & $\mathrm{w} /-$ \\
\hline Oxaloacetic acid & + & + & + & $+1-$ \\
\hline Propionic acid & $\mathrm{w}$ & + & + & $+1-$ \\
\hline D-Sorbitol & - & - & - & $\mathrm{w} /-$ \\
\hline Thiosulfate & + & - & + & $+1-$ \\
\hline Urea & + & - & + & $+1-$ \\
\hline
\end{tabular}

asymbioticus (Hahn et al., 2009). Due to this weak performance and so that the strains could be compared with the previously investigated strains of the genus Polynucleobacter, tests on the utilization of various organic compounds were not performed with sole substrate media or by using commercially available test kits. Instead, experiments were performed by applying the method previously used for strains of $P$. necessarius (Hahn et al., 2009). Briefly, growth enabled by the utilization of a specific substrate was determined by comparison of the optical density (OD) established in liquid one-tenthstrength NSY medium $\left(0.3 \mathrm{~g} \mathrm{l}^{-1}\right)$ with and without $0.5 \mathrm{~g} \mathrm{l}^{-1}$ test substance. OD differences of $<10 \%$, of 10 $50 \%$ and of $>50 \%$ of the OD established on the medium without the test substance were scored after 10 days of growth as no utilization (-), weak utilization (w) and good utilization $(+)$, respectively.

Sequencing and phylogenetic analyses of the 16S rRNA genes were performed as described previously (Hahn, 2003; Hahn et al., 2005). Neighbour-joining trees were calculated by using MEGA4 software (Tamura et al., 2007) and maximum-likelihood trees were generated by using the RaxML web server (Stamatakis et al., 2008). Morphological characterization of the proposed type strain, strain MWHMoIso2 ${ }^{\mathrm{T}}$, by electron microscopy was performed as described previously (Yakimov et al., 1998). The G+C content of DNA was determined according to the method of Tóth et al. (2008). Fatty acid methyl esters (FAMEs) were obtained as described previously (Kämpfer \& Kroppenstedt, 1996) and separated by a gas chromatograph (model 6890, Hewlett Packard). Peaks were automatically computed using the Microbial Identification standard software package (Sasser, 1990).

The five strains investigated were similar to strains of $P$. necessarius subsp. necessarius in that they produced only low yields of biomass in relatively rich media (Hahn et al., 2009). Biomass yields were usually one order of magnitude lower than found for other members of the family Burkholderiaceae. The results of the chemotaxonomic and phenotypic characterization of the novel strains are presented in Tables 1, 2 and 3. Experiments on the utilization capabilities of three of the novel strains (MWHMoIso2 ${ }^{\mathrm{T}}$, MWH-CaK1 and MWH-VicM1) resulted only in $68 \%$ of the 37 tested substrates giving identical results (three categories; i.e. no, weak and good utilization) (Table 2). Testing of four strains of $P$. necessarius subsp. asymbioticus with the same substrates yielded identical results for only $25 \%$ of the tested substrates (Hahn et al., 2009). Despite the relatively large number of substrates tested, no discriminating traits were found between the three novel strains and the four strains of $P$. necessarius subsp. asymbioticus (Table 2). Therefore, the utilization patterns of the remaining two novel strains, i.e. MWHTaW3 and MWH-NZ8W13, were not examined. All of the novel strains grew in NSY medium as curved rods with small cell sizes (Fig. 1). Doubling times for growth in liquid NSY medium at $20{ }^{\circ} \mathrm{C}$ were $4.5,5.7$, and $5.9 \mathrm{~h}$ for strains 
Table 3. Whole-cell fatty acid contents of the novel strains and $P$. necessarius subsp. asymbioticus QLW-P1DMWA-1 ${ }^{\top}$

Strains: 1, MWH-MoIso2 $2^{\mathrm{T}}$; 2, MWH-CaK1; 3, MWH-VicM1; 4, MWH-TaW3; 5, MWH-NZ8W13; 6, P. necessarius subsp. asymbioticus QLW-P1DMWA-1 ${ }^{\mathrm{T}}$ (Hahn et al., 2009). Values are percentages of the summed fatty acids named in the peak library of the MIDI system (contents $>0.2 \%$ ). Strains were grown on R2A agar plates for $3-5$ days at $28{ }^{\circ} \mathrm{C}$.

\begin{tabular}{|lrrrrrr|}
\hline Fatty acid & $\mathbf{1}$ & $\mathbf{2}$ & $\mathbf{3}$ & $\mathbf{4}$ & $\mathbf{5}$ & $\mathbf{6}$ \\
\hline Saturated & & & & & & \\
$\mathrm{C}_{12: 0}$ & - & - & - & - & - & 3.4 \\
$\mathrm{C}_{14: 0}$ & 0.7 & 0.6 & 0.9 & 2.3 & 1.3 & 0.9 \\
$\mathrm{C}_{15: 0}$ & 0.2 & - & 0.2 & - & - & 0.3 \\
$\mathrm{C}_{16: 0}$ & 15.4 & 11.0 & 11.1 & 14.9 & 13.5 & 22.2 \\
$\mathrm{C}_{18: 0}$ & 0.8 & 0.7 & 0.5 & 1.1 & 1.1 & 1.2 \\
Unsaturated & & & & & & \\
$\mathrm{C}_{14: 1} \omega 5 c$ & 0.6 & 0.4 & 0.6 & - & 1.1 & - \\
$\mathrm{C}_{16: 1} \omega 5 c$ & 0.3 & 0.5 & 0.5 & 1.1 & - & 0.9 \\
$\mathrm{C}_{17: 1} \omega 6 c$ & 0.5 & 0.3 & 0.7 & - & - & - \\
$\mathrm{C}_{18: 1} \omega 9 c$ & 0.3 & - & 0.2 & 2.0 & - & - \\
$\mathrm{C}_{18: 1} \omega 7 c$ & 28.7 & 37.5 & 35.6 & 33.7 & 38.1 & 12.9 \\
$\mathrm{C}_{18: 1} \omega 5 c$ & 0.2 & 0.2 & 0.2 & - & - & - \\
11 Methyl-C $\mathrm{C}_{18: 1} \omega 7 c$ & 3.7 & 2.2 & 0.4 & 1.0 & 2.3 & 3.1 \\
Hydroxylated & & & & & & \\
$\mathrm{C}_{12: 0} 2-\mathrm{OH}$ & - & - & - & - & - & 2.5 \\
$\mathrm{C}_{12: 0} 3-\mathrm{OH}$ & 11.1 & 9.9 & 7.1 & 11.2 & 10.5 & - \\
Summed features & & & & & & \\
1 ( $\mathrm{C}_{12: 0} \mathrm{ALDE}$ ) & 0.1 & - & 0.2 & - & - & 0.4 \\
2 (including $\mathrm{C}_{14: 0}$ & 0.6 & 0.7 & 3.9 & 0.8 & 0.6 & 9.6 \\
3-OH) & & & & & & \\
3 (including $\left.\mathrm{C}_{16: 1} \omega 7 c\right)$ & 34.7 & 35.4 & 36.5 & 32.0 & 31.5 & 41.3 \\
7 (including $\left.\mathrm{C}_{19: 1} \omega 6 c\right)$ & 1.5 & 0.7 & 0.6 & - & - & 0.4 \\
& & & & & & \\
\hline
\end{tabular}

MWH-VicM1, MWH-MoIso2 ${ }^{\mathrm{T}}$, and MWH-CaK1, respectively. All three novel strains grew under these conditions with mean cell volumes of $<0.1 \mu \mathrm{m}^{3}$ (Hahn, 2003).

The major components of the whole-cell fatty acids were $\mathrm{C}_{16: 1} \omega 7 c, \mathrm{C}_{18: 1} \omega 7 c, \mathrm{C}_{16: 0}$ and $\mathrm{C}_{12: 0} 3-\mathrm{OH}$ (Table 3). The fatty acid pattern of strains of $P$. necessarius was dominated by the same non-hydroxylated acids (Table 3 and Hahn et al., 2009). The occurrence of several other fatty acids in minor amounts was shared by $P$. necessarius and all of the novel strains studied. Minor fatty acids were $\mathrm{C}_{14: 0}, \mathrm{C}_{18: 0}$, and 11 methyl- $\mathrm{C}_{18: 1} \omega 7 \mathrm{c}$. The novel strains could be clearly distinguished from strains of $P$. necessarius by the absence of $\mathrm{C}_{12: 0}$ and $\mathrm{C}_{12: 0} 2-\mathrm{OH}$ and the presence of high amounts $(>7 \%)$ of $\mathrm{C}_{12: 0}$ 3-OH. In all P. necessarius strains studied so far, no $\mathrm{C}_{12: 0} 3-\mathrm{OH}$ has been detected, and the $\mathrm{C}_{12: 0}$ and $\mathrm{C}_{12: 0} 3-\mathrm{OH}$ contents were higher than $3 \%$ and $1 \%$, respectively (Hahn et al., 2009). Furthermore, MIDI summed feature 2, including $\mathrm{C}_{14: 0} 3-\mathrm{OH}$ was present in the novel strains in much lower amounts $(<4 \%)$ than in strains of $P$. necessarius $(>9 \%)$. The content of fatty acid $\mathrm{C}_{18: 1} \omega 7 \mathrm{c}$ was $>28 \%$ in the novel strains but was $<21 \%$ in strains of $P$. necessarius.

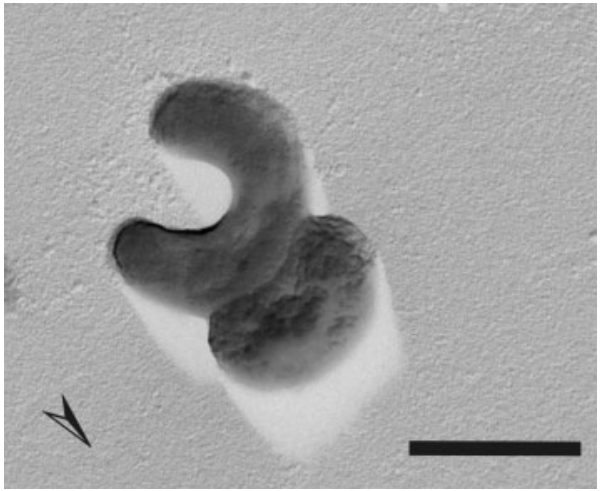

Fig. 1. Transmission electron microscope survey view of $\mathrm{Pt}-\mathrm{C}$ shadow-cast cells of strain $\mathrm{MWH}-\mathrm{Molso} 2^{\top}$. The arrowheads indicate the direction of shadow casting. Bar, $500 \mathrm{~nm}$.

The genome sizes of the five novel strains were not determined, however, the genome sizes of strains tentatively assigned to the proposed taxon range from 1.9 to 2.1 Mbp (Vannini et al., 2007), which may indicate that the novel strains possess smaller genome sizes than strains of $P$. necessarius subsp. asymbioticus.

\section{Phylogeny}

Phylogenetic analyses of the 16S rRNA genes of the five novel strains revealed clustering of the strains in a monophyletic clade representing a sibling taxon of $P$. necessarius (Fig. 2). The minimum $16 \mathrm{~S}$ rRNA sequence similarity of the five strains was 99.3\% (sequence stretches ranging from Escherichia coli positions 28-1542 were analysed). The sequence similarity between the $16 \mathrm{~S}$ rRNA genes of strain $\mathrm{MWH}-\mathrm{MoIso} 2^{\mathrm{T}}$ and the type strain of $P$. necessarius subsp. asymbioticus and a sequence representing $P$. necessarius subsp. necessarius $\mathrm{E} 24$ were $97.3 \%$ and $96.8 \%$, respectively. BLAST searches with the 16S rRNA gene sequences of the novel strains and subsequent phylogenetic analyses revealed that the five novel strains formed a tight monophyletic cluster together with 99 cultured and uncultured strains (data not shown). This cluster was phylogenetically identical with the previously characterized 'Polynucleobacter subcluster D' (Hahn, 2003) for which a minimum within-cluster sequence similarity of $99.1 \%$ has been reported (Wu \& Hahn, 2006). Phylogenetic analysis of the 16S-23S ITS sequences confirmed the separate clustering of the five novel strains and previously investigated strains of $P$. necessarius and demonstrated tight clustering of the sequences within both groups (Fig. 3).

\section{Genotypic traits}

All members of the 'Polynucleobacter subcluster D' possessed the oligonucleotide sequence $5^{\prime}-\mathrm{AA}(\mathrm{T} /$ G)CCCT(A/T)AGGGGGAAA-3' within the 16S rRNA gene (E. coli positions 181-197). In almost all cases, the 


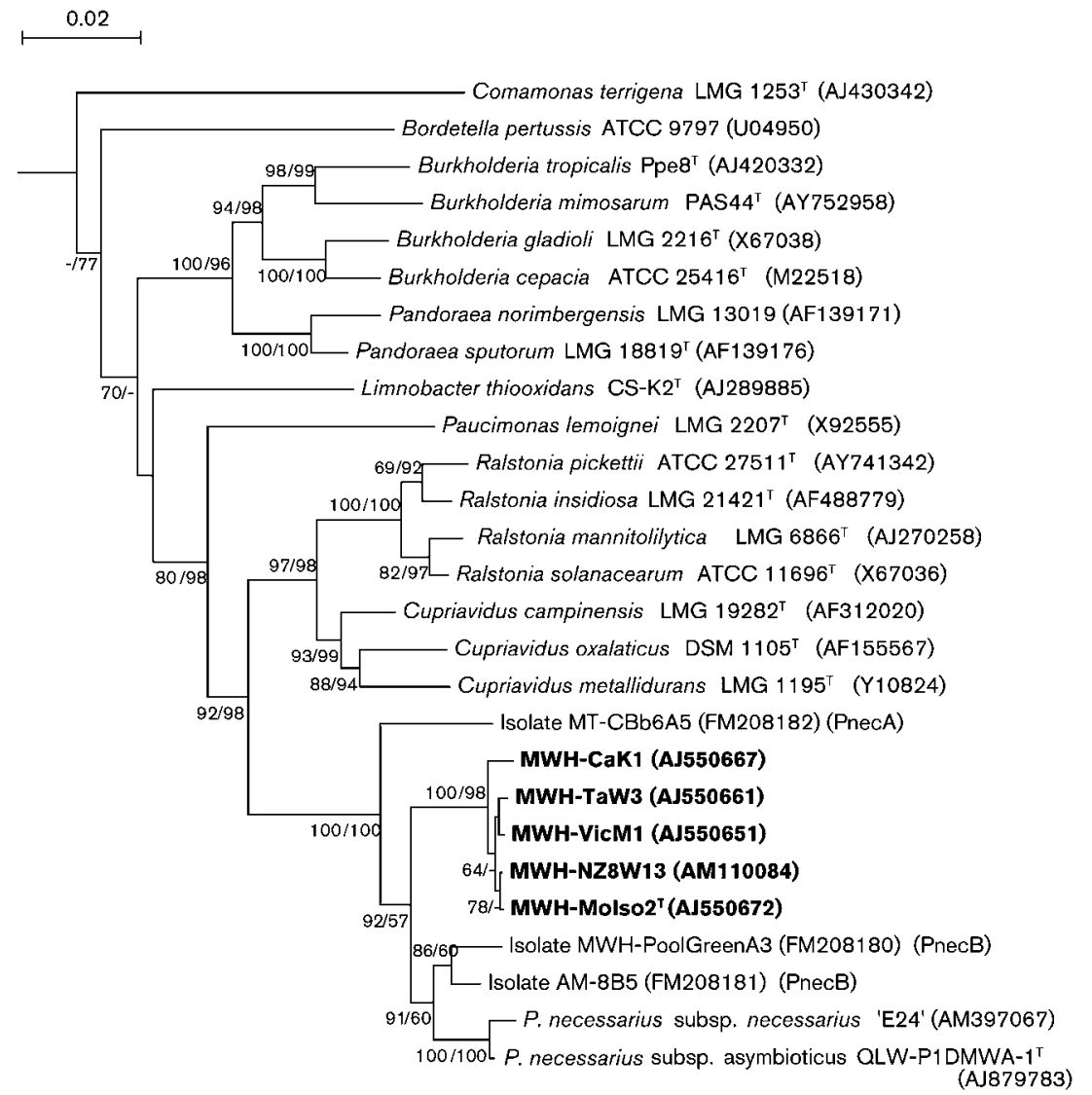

Fig. 2. Neighbour-joining (NJ) phylogenetic tree based on almost complete 16S rRNA gene sequences, showing the phylogenetic position of the five novel strains within the family Burkholderiaceae. A maximum-likelihood (ML) tree (not shown) calculated with the same sequence set differed from the NJ tree in the positions of Bordetella pertussis and Limnobacter thiooxidans. Bootstrap values obtained by the NJ (first value) and the $\mathrm{ML}$ algorithm (second value) are shown if at least one value was $>60 \%$. PnecA, 'Polynucleobacter subcluster A'; PnecB, 'Polynucleobacter subcluster B'. Bar, 0.02 substitutions per nucleotide position.

presence of this sequence could be determined by fluorescent in situ hybridization of whole cells by using a mixture of the fluorescently labelled oligonucleotide probes PnecD1-181 and PnecD2-181 (Hahn et al., 2005). The sequences of these two probes differ in the second variable position (E. coli position 188) of the diagnostic sequence, but not in the first variable position (E. coli position 183). Analysis of 104 sequences forming the phylogenetic cluster representing the proposed new taxon, Polynucleobacter cosmopolitanus sp. nov., demonstrated that only one of the novel strains differed from the probe sequences in the first variable position of the diagnostic sequence. Besides the FISH probe, a reverse line blot hybridization probe (PolynucD123-144) for the detection of the proposed new taxon in environmental samples has been developed and applied successfully (Wu et al., 2007).
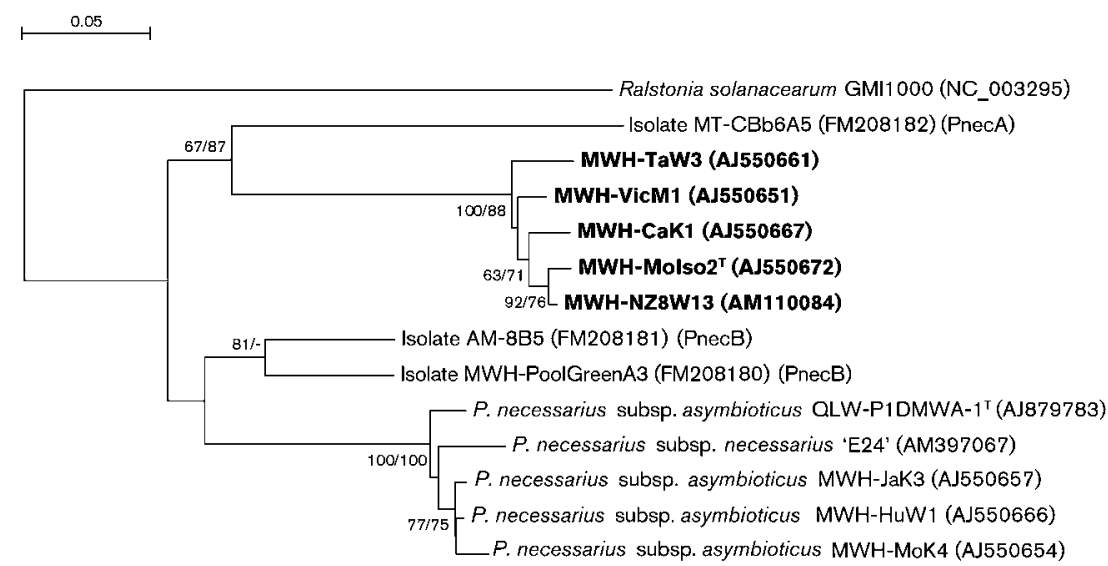

Fig. 3. Neighbour-joining (NJ) phylogenetic tree based on complete 16S-23S ITS sequences (approx. length $500 \mathrm{bp}$ ). The five novel strains are shown in bold type. Sequences of strains affiliated with the PnecA and PnecB groups were included in this analysis. A ML tree (not shown) calculated with the same sequence set confirmed the tight clustering of the $P$. cosmopolitanus $\mathrm{sp}$. nov. strains, as well as the tight clustering of the $P$. necessarius strains (bootstrap value $100 \%)$. Bootstrap values obtained by the NJ (first value) and the ML algorithm (second value) are shown if at least one value was $>60 \%$. Bar, 0.05 substitutions per nucleotide position. 


\section{Biogeography of $\boldsymbol{P}$. cosmopolitanus sp. nov.}

Strains affiliated to the phylogenetic cluster represented by $P$. cosmopolitanus sp. nov. were isolated from freshwater habitats located in Eurasia, South America, Africa and Oceania (Hahn, 2003; M. W. Hahn, Q. L. Wu, M Pöckl, K. Simek \& U. Brandt, unpublished data). A strain has even been isolated from a freshwater habitat located on the Hawaiian Archipelago (strain MWH-Haw2W10a, GenBank accession no. AM110098). Recently, many strains have been isolated from various lakes located in Japan (Watanabe et al., 2009). Furthermore, cultivation-independent investigations have indicated the presence of this novel taxon at various locations, including Northern America (Crump et al., 1999; Zwart et al., 2002; Simpson et al., 2004; Crump \& Hobbie, 2005), a river estuary of northern Taiwan (Liao et al., 2007) and in running water in Germany (Beier et al., 2008). The phylogenetic group representing the proposed novel species has even been detected by cultivation-independent methods in a pond located at the Tibetan Plateau at an altitude of $3210 \mathrm{~m}$ above sea level (Wu et al., 2006). The geographical distribution of habitats colonized by strains phylogenetically belonging to the proposed novel species clearly indicates a cosmopolitan distribution of the new taxon over all continents and all climatic zones.

\section{Ecology of $\boldsymbol{P}$. cosmopolitanus sp. nov.}

Members of the phylogenetic cluster represented by the proposed novel species have been isolated and detected in the water columns of running and stagnant freshwater habitats such as ponds, lakes and streams. A recent investigation compared the salinity tolerance determined by ecophysiological experiments with six pure culture strains of the proposed new taxon with the occurrence of the taxon along a salinity gradient of sixteen lakes ( $\mathrm{Wu}$ et al., 2006). This gradient ranged from $0.2 \mathrm{~g} \mathrm{l}^{-1}$ (freshwater) to $222 \mathrm{~g} \mathrm{l}^{-1}$ salinity (hypersaline). While the novel strains tested grew in the laboratory up to maximum salinities of 3.6-5.6 $\mathrm{g} \mathrm{NaCl}^{-1}$ (note that the salinity tolerance considers the total amount of dissolved salt, while the $\mathrm{NaCl}$ tolerance mentioned above considers exclusively the $\mathrm{NaCl}$ added to the medium but not the other salts contained in the medium), the taxon was detected in situ by cultivation-independent methods exclusively in habitats with salinities $<1 \mathrm{~g} \mathrm{l}^{-1}$. However, the new taxon has also been detected in a metagenomic study of two estuaries and a salinity of $3.5 \mathrm{~g} \mathrm{l}^{-1}$ (oligosaline) was reported for one of these estuaries (Chesapeake Bay, MD, USA) (Shaw et al., 2008). The detection of the novel taxon has never been reported at terrestrial or offshore marine sites. All these observations indicate that the new taxon is mainly found in the water column of freshwater habitats, but may also occur in oligosaline habitats, and that it is absent from eusaline (oceans) and hypersaline environments.

The new taxon could be detected by the FISH probes PnecD1-181/PnecD2-181 in several habitats (Wu \& Hahn, 2006; Q. L. Wu and M. W. Hahn, unpublished data). In a survey of 60 freshwater lakes, the proposed new taxon was detected by FISH in 15 habitats. Usually, the level of detection ranged from $0 \%$ (below the detection limit by FISH) to $0.9 \%$ of the total prokaryotic numbers. The highest recorded relative abundance of $8.1 \%$ of total prokaryotic cells was observed in a freshwater pond located on the Tibetan Plateau (see above). All cells detected by the probes in the various habitats investigated possessed a curved rod morphology. In a seasonal study on the shallow eutrophic Lake Taihu located in subtropical China, two population peaks, with $0.3 \%$ relative abundance (equalling $1 \times 10^{4}$ cells ml$^{-1}$ ) could be observed in winter and late spring (Wu \& Hahn, 2006).

In a study focusing on the vulnerability of strains affiliated with the new taxon to predation by bacterivorous flagellates, a relatively low vulnerability was observed (Boenigk et al., 2004). Predation by such flagellates in general represents a major mortality factor for planktonic freshwater bacteria (Hahn \& Höfle, 2001). The low vulnerability found was explained by the small cell sizes of the strains $\left(<0.1 \mu \mathrm{m}^{3}\right.$, ultramicrobacteria); however, a complete resistance to predation was not observed. Thus, factors determining the occurrence and relative abundance of the novel taxon in various freshwater habitats remain to be revealed.

The results from the phylogenetic analysis and chemotaxonomic investigations demonstrated pronounced differences between the five novel strains and strains of $P$. necessarius (Figs 2 and 3, Table 4). Furthermore, the $16 \mathrm{~S}$ rRNA gene sequence similarities of $\leqslant 97.3 \%$ between the type strain of the proposed novel species and the strains

Table 4. Characteristics that discriminate $P$. cosmopolitanus sp. nov. and $P$. necessarius subsp. asymbioticus

Taxa: 1, P. cosmopolitanus sp. nov.; 2, P. necessarius subsp. asymbioticus. Note that only an incomplete phenotypic and chemotaxonomic description of $P$. necessarius subsp. necessarius is available because of its obligately endosymbiotic lifestyle. ND, Not detected.

\begin{tabular}{|c|c|c|}
\hline Characteristic & 1 & 2 \\
\hline \multicolumn{3}{|l|}{ Fatty acid } \\
\hline $\mathrm{C}_{12: 0}$ & $\mathrm{ND}$ & $>3 \% *$ \\
\hline $\mathrm{C}_{18: 1} \omega 7 c$ & $>28 \% *$ & $<21 \% *$ \\
\hline $\mathrm{C}_{12: 0} 2-\mathrm{OH}$ & ND & $>1 \%^{*}$ \\
\hline $\mathrm{C}_{12: 0} 3-\mathrm{OH}$ & $>7 \% *$ & ND \\
\hline Summed feature 2 (including $\mathrm{C}_{14: 0} 3-\mathrm{OH}$ ) & $<4 \%{ }^{*}$ & $>9 \%{ }^{*}$ \\
\hline Probe PnecC-16S-445† & - & + \\
\hline Probe PnecD-181‡ & + & - \\
\hline
\end{tabular}

${ }^{\star}$ Percentages of the summed fatty acids named in the peak library of the MIDI system.

$\dagger$ Hahn et al. (2005).

¥Equal mixture of probes PnecD1-181 and PnecD2-181 (Hahn et al., 2005). 
representing the two subspecies of $P$. necessarius suggest that strain $\mathrm{MWH}-\mathrm{MoIso} 2^{\mathrm{T}}$ represents a novel species (Stackebrandt \& Ebers, 2006). The coherence of the taxon represented by the five novel strains could not be checked by DNA-DNA hybridization experiments due to the limitations in the production of sufficient amounts of DNA. However, the phylogenetic analysis of the 16S rRNA gene sequences and of the much less conserved 16S-23S ITS sequences of Polynucleobacter spp. strains (Fig. 3) strongly indicate that the five novel strains represent a coherent taxon. The latter phylogenetic marker is much less conserved than 16S rRNA gene sequences, thus significant intra-taxon heterogeneity would be expected to be indicated by this marker. It is suggested that strain MWH-MoIso2 ${ }^{\mathrm{T}}$ and the four other new strains represent a novel species for which the name Polynucleobacter cosmopolitanus sp. nov. is proposed.

\section{Description of Polynucleobacter cosmopolitanus sp. nov.}

Polynucleobacter cosmopolitanus (cos.mo.po.li'ta.nus. Gr. adj. kosmopolites an inhabitant of the world, a cosmopolitan; N.L. masc. adj. cosmopolitanus cosmopolitan).

Curved, non-motile rods, $0.5-1.4 \mu \mathrm{m}$ in length and $0.3-$ $0.5 \mu \mathrm{m}$ in width. Chemo-organotrophic, aerobic strains, at least some of the strains are able to grow anaerobically. Can be cultivated on NSY, R2A, and Bacto peptone media, and some other complex media at concentrations of $\leqslant 3 \mathrm{~g} \mathrm{l}^{-1}$. Colonies grown on NSY agar are unpigmented, circular and convex with smooth surfaces and reach a diameter of $1 \mathrm{~mm}$ after $5-10$ days at $20-24{ }^{\circ} \mathrm{C}$. Growth occurs at $10-$ $35{ }^{\circ} \mathrm{C}$, four strains also grow at $5{ }^{\circ} \mathrm{C}$ and two strains are able to grow at $38{ }^{\circ} \mathrm{C}$. Grows without $\mathrm{NaCl}$. Maximum $\mathrm{NaCl}$ concentration tolerated is strain dependent and ranges from 0.3 to $0.5 \%(\mathrm{w} / \mathrm{v})$. Utilizes acetate, pyruvate, propionate, oxaloacetate, malate, succinate, fumarate, Dgalacturonic acid, D-galactose, L-cysteine and L-alanine when these substrates are provided in a medium containing low amounts of NSY. None of the strains utilize formate, glycolate, oxalate, D-lyxose, D-fructose, D-fucose, D-sorbitol, L-aspartate, L-serine, L-asparagine or betaine. Major cellular fatty acids are $\mathrm{C}_{18: 1} \omega 7 c, \mathrm{C}_{16: 0}$ and $\mathrm{C}_{12: 0} 3-\mathrm{OH}$. No 2-hydroxylated compounds are detected. Fractions of natural populations pass through $0.2 \mu \mathrm{m}$ filters. Can be distinguished from $P$. necessarius by using the $P$. necessarius-specific FISH probe PnecC-16S-445 (Hahn et al., 2009), as well as by differences in fatty acid profiles (Table 3 ). In contrast to $P$. necessarius, exclusively free-living strains and no endosymbiotic strains are reported, however, the existence of endosymbiotic strains cannot be completely excluded at present. Tentatively, all strains possessing the oligonucleotide sequence $5^{\prime}$-AA(T/G)CCCT(A/T)AGGGGGAAA-3' (E. coli positions 181-197) within the 16S rRNA gene shall be assigned to the proposed species. In almost all cases (with one known exception), the presence of this diagnostic sequence can be determined by FISH with a mixture of the two probes PnecD1-181 and PnecD2181 (Hahn et al., 2005).

The type strain, MWH-MoIso2 ${ }^{\mathrm{T}}\left(=\mathrm{DSM} \quad 21490^{\mathrm{T}}=\mathrm{CIP}\right.$ $109840^{\mathrm{T}}=$ LMG $\left.25212^{\mathrm{T}}\right)$, was isolated from the water column (pelagic zone) of Lake Mondsee located in the Salzkammergut Lake District in Austria (Hahn, 2003). The DNA $G+C$ content of the type strain is $44.9 \%$. Four other reference strains are available: MWH-CaK1 (=DSM 21494), MWH-VicM1 (=DSM 21486); MWH-TaW3 (=DSM 21487) and MWH-NZ8W13 (=DSM 21488).

\section{Acknowledgements}

We are grateful to R. M. Kroppenstedt for performing the fatty acid analyses, to P. Schumann for determining the $\mathrm{G}+\mathrm{C}$ content and to M. Kopitz and M. Pöckl for technical assistance. This study was supported by the Austrian Science Fund (Projects P15655 and P19853 granted to M.W.H.).

\section{References}

Alonso, C., Zeder, M., Piccini, C., Conde, D. \& Pernthaler, J. (2009). Ecophysiological differences of betaproteobacterial populations in two hydrochemically distinct compartments of a subtropical lagoon. Environ Microbiol 11, 867-876.

Beier, S., Witzel, K. P. \& Marxsen, J. (2008). Bacterial community composition in central European running waters examined by temperature gradient gel electrophoresis and sequence analysis of 16S rRNA genes. Appl Environ Microbiol 74, 188-199.

Boenigk, J., Stadler, P., Wiedlroither, A. \& Hahn, M. W. (2004). Strainspecific differences in the grazing sensitivities of closely related ultramicrobacteria affiliated with the Polynucleobacter cluster. Appl Environ Microbiol 70, 5787-5793.

Crump, B. C. \& Hobbie, J. E. (2005). Synchrony and seasonality in bacterioplankton communities of two temperate rivers. Limnol Oceanogr 50, 1718-1729.

Crump, B. C., Armbrust, E. V. \& Baross, J. A. (1999). Phylogenetic analysis of particle-attached and free-living bacterial communities in the Columbia River, its estuary, and the adjacent coastal ocean. Appl Environ Microbiol 65, 3192-3204.

Hahn, M. W. (2003). Isolation of strains belonging to the cosmopolitan Polynucleobacter necessarius cluster from freshwater habitats located in three climatic zones. Appl Environ Microbiol 69, 5248-5254.

Hahn, M. W. \& Höfle, M. G. (2001). Grazing of protozoa and its effect on populations of aquatic bacteria. FEMS Microbiol Ecol 35, 113-121.

Hahn, M. W., Stadler, P., Wu, Q. L. \& Pöckl, M. (2004). The filtrationacclimatization method for isolation of an important fraction of the not readily cultivable bacteria. J Microbiol Methods 57, 379-390.

Hahn, M. W., Pöckl, M. \& Wu, Q. L. (2005). Low intraspecific diversity in a Polynucleobacter subcluster population numerically dominating bacterioplankton of a freshwater pond. Appl Environ Microbiol 71, 4539-4547.

Hahn, M. W., Lang, E., Brandt, U., Wu, Q. L. \& Scheuerl, T. (2009). Emended description of the genus Polynucleobacter and the species Polynucleobacter necessarius and proposal of two subspecies, $P$. necessarius subsp. necessarius subsp. nov. and P. necessarius subsp. asymbioticus subsp. nov. Int J Syst Evol Microbiol 59, 2002-2009.

Heckmann, K. \& Schmidt, H. J. (1987). Polynucleobacter necessarius gen. nov., sp. nov., an obligately endosymbiotic bacterium living in the cytoplasm of Euplotes aediculatus. Int J Syst Bacteriol 37, 456-457. 
Kämpfer, P. \& Kroppenstedt, R. M. (1996). Numerical analysis of fatty acid patterns of coryneform bacteria and related taxa. Can J Microbiol 42, 989-1005.

Liao, P. C., Huang, B. H. \& Huang, S. (2007). Microbial community composition of the Danshui river estuary of northern Taiwan and the practicality of the phylogenetic method in microbial barcoding. Microb Ecol 54, 497-507.

Salcher, M. M., Pernthaler, J., Zeder, M., Psenner, R. \& Posch, T. (2008). Spatio-temporal niche separation of planktonic Betaproteobacteria in an oligo-mesotrophic lake. Environ Microbiol 10, 20742086.

Sasser, M. (1990). Identification of bacteria by gas chromatography of cellular fatty acids, MIDI Technical Note 101. Newark, DE: MIDI Inc.

Shaw, A. K., Halpern, A. L., Beeson, K., Tran, B., Venter, J. C. \& Martiny, J. B. (2008). It's all relative: ranking the diversity of aquatic bacterial communities. Environ Microbiol 10, 2200-2210.

Simpson, J. M., Santo Domingo, J. W. \& Reasoner, D. J. (2004). Assessment of equine fecal contamination: the search for alternative bacterial source-tracking targets. FEMS Microbiol Ecol 47, 65-75.

Springer, N., Amann, R., Ludwig, W., Schleifer, K. H. \& Schmidt, H. (1996). Polynucleobacter necessarius, an obligate bacterial endosymbiont of the hypotrichous ciliate Euplotes aediculatus, is a member of the beta-subclass of Proteobacteria. FEMS Microbiol Lett 135, 333-336.

Stackebrandt, E. \& Ebers, J. (2006). Taxonomic parameters revisited: tarnished gold standard. Microbiol Today 33, 152-155.

Stamatakis, A., Hoover, P. \& Rougemont, J. A. (2008). A rapid bootstrap algorithm for the RAxML web servers. Syst Biol 57, 758-771.

Tamura, K., Dudley, J., Nei, M. \& Kumar, S. (2007). MEGA4: molecular evolutionary genetics analysis (MEGA) software version 4.0. Mol Biol Evol 24, 1596-1599.

Tóth, E. M., Kéki, Z., Homonnay, Z. G., Borsodi, A. K., Márialigeti, K. \& Schumann, P. (2008). Nocardioides daphniae sp. nov., isolated from
Daphnia cucullata (Crustacea: Cladocera). Int J Syst Evol Microbiol 58, 78-83.

Vannini, C., Pöckl, M., Petroni, G., Wu, Q. L., Lang, E., Stackebrandt, E., Schrallhammer, M., Richardson, P. M. \& Hahn, M. W. (2007). Endosymbiosis in statu nascendi: close phylogenetic relationship between obligately endosymbiotic and obligately free-living Polynucleobacter strains (Betaproteobacteria). Environ Microbiol 9, 347-359.

Watanabe, K., Komatsu, N., Ishii, Y. \& Negishi, M. (2009). Effective isolation of bacterioplankton genus Polynucleobacter from freshwater environments grown on photochemically degraded dissolved organic matter. FEMS Microbiol Ecol 67, 57-68.

Wu, Q. L. \& Hahn, M. W. (2006). Differences in structure and dynamics of Polynucleobacter communities in a temperate and a subtropical lake revealed at three phylogenetic levels. FEMS Microbiol Ecol 57, 67-79.

Wu, Q. L., Schauer, M., Kamst-Van Agterveld, M. P., Zwart, G. \& Hahn, M. W. (2006). Bacterioplankton community composition along a salinity gradient of sixteen high-mountain lakes located on the Tibetan Plateau, China. Appl Environ Microbiol 72, 5478-5485.

Wu, Q. L., Zwart, G., Wu, J., Kamst-van Agterveld, M. P., Liu, S. \& Hahn, M. W. (2007). Submersed macrophytes play a key role in structuring bacterioplankton community composition in the large, shallow, subtropical Taihu Lake, China. Environ Microbiol 9, 27652774.

Yakimov, M. M., Golyshin, P. N., Lang, S., Moore, E. R. W., Abraham, W.-R., Lünsdorf, H. \& Timmis, K. N. (1998). Alcanivorax borkumensis gen. nov., sp. nov., a new hydrocarbon-degrading and surfactant producing marine bacterium. Int J Syst Bacteriol 48, 339-348.

Zwart, G., Crump, B. C., Kamst-van Agterveld, M. P., Hagen, F. \& Han, S.-K. (2002). Typical freshwater bacteria: an analysis of available 16S rRNA gene sequences from plankton of lakes and rivers. Aquat Microb Ecol 28, 141-155. 